\title{
Development of a new probe for specific and sensitive detection of 'Candidatus Phytoplasma mali' in inoculated apple trees
}

\author{
M. Aldaghi ${ }^{1,2, *}$, S. Massart ${ }^{1, *}$, S. Roussel ${ }^{1} \&$ M.H. Jijakli ${ }^{1}$ \\ 1 Plant Pathology Unit, Gembloux Agricultural University, Gembloux, Belgium \\ 2 Plant Diseases Research Department, Plant Pests \& Diseases Research Institute, Tehran, Iran \\ *These authors equally contributed to this paper.
}

\section{Keywords}

'Candidatus Phytoplasma mali'; detection; real-time PCR; sensitivity.

\section{Correspondence}

M.H. Jijakli, Plant Pathology Unit, Gembloux Agricultural University, Passage des déportés 2, 5030 Gembloux, Belgium.

Email: jijakli.h@fsagx.ac.be

Received: 7 December 2006; revised version accepted: 11 June 2007

doi:10.1111/j.1744-7348.2007.00171.x

\begin{abstract}
A new TaqMan minor groove binding (MGB) probe and new PCR conditions were designed for quick, specific and sensitive detection of 'Candidatus Phytoplasma mali'. The new probe can distinguish a single mismatch between ' $\mathrm{Ca}$. P. mali' and 'Candidatus Phytoplasma prunorum', this constituting an improvement over a previously published method. In our study, the relative position of the mismatch in the MGB probe influenced greatly the specificity of detection. Our new real-time PCR protocol was able to detect one plasmid copy in water and 100 copies in healthy plant DNA extracts. The sensitivity of this new real-time PCR method, three other real-time PCR protocols and a conventional PCR with fU5/rU3 primers was compared. Periwinkles and MM106 rootstocks were grafted with infected material and surveyed over time by symptom observation, conventional PCR and real-time PCR. Phytoplasma infection was detected by symptom observation in all periwinkles within 4 months and in $75 \%$ of the MM106 rootstocks by the end of 7 months. Conventional PCR detected phytoplasma infection in all periwinkles within 4 months and in all MM106 rootstocks within 7 months. Best results were obtained by our realtime PCR, which detected phytoplasma infection in all grafted plants within 3 months after inoculation.
\end{abstract}

\section{Introduction}

Phytoplasmas are prokaryotes inhabiting phloem sieve elements of infected plants (McCoy et al., 1989; Lee et al., 1995). 'Candidatus Phytoplasma mali' (Seemüller \& Schneider, 2004), classified as an A2 pest by European and Mediterranean Plant Protection Organization (EPPO), is a quarantine organism (EPPO/CABI, 1996) associated with one of the most serious diseases of apple trees, apple proliferation disease, in most countries of western Europe (Frisinghelli et al., 2000). Typical symptoms are witches' broom, early leaf colouration in autumn and small size and incomplete colouration of fruit. This phytoplasma belongs to the 16SrX group, which also includes 'Candidatus Phytoplasma pyri' and
'Candidatus Phytoplasma prunorum' (Seemüller et al., 1998). Phylogenetic analyses have revealed that these pathogens have nearly identical 16S rDNA sequences (Seemüller \& Schneider, 2004). Restriction fragment length polymorphism analysis of chromosomal DNA has demonstrated their relationship (Lee et al., 1998; Aldaghi et al., 2005).

Candidatus Phytoplasma mali being a quarantine organism, its accurate and rapid detection is a major prerequisite to controlling the disease and fulfilling the certification requirements. Yet the relatively low titres and uneven distribution of phytoplasmas in plant hosts (Andersen et al., 1998) and their inability to be cultured in vitro make it hard to develop an accurate and reliable diagnostic procedure. 
Real-time PCR provides a straightforward method for sensitive and specific detection of phytoplasmas (Jarausch et al., 2004). Recently, Torres et al. (2005) developed a polyvalent real-time PCR protocol based on SYBR Green technology for simultaneous detection and quantification of the three phytoplasmas of the 16SrX group. SYBR Green technology has also been used to quantify Ca. P. mali in plants and insect vectors (Jarausch et al., 2004). Baric \& Dalla-Via (2004) have developed a new approach to specific detection of $\mathrm{Ca}$. P. mali in plant material: a real-time PCR assay using a TaqMan minor groove binding (MGB) probe. The MGB moiety stabilise probe hybridisation with single-stranded DNA targets, raising the melting temperature of the oligodeoxynucleotide. This property allows the use of shorter oligodeoxynucleotide (Kutyavin et al., 2000). TaqMan MGB probes display higher specificity than classical TaqMan probes (Yao et al., 2006). Successful discrimination of a single mismatch has been achieved by various authors (Marbot et al., 2002; Salmon et al., 2002a; Yoshitomi et al., 2003; Van Hoeyveld et al., 2004; Massart et al., 2005). Yet, recent studies (Yao et al., 2006) have shown that a TaqMan MGB probe may tolerate one or two mismatches with its template and cause a nonspecific fluorescence emission.

The aim of the present study was to develop a new real-time PCR methodology for specifically detecting Ca. P. mali infection in apple trees. The specificity of the methodology described by Baric \& Dalla-Via (2004) was improved by designing a new MGB probe and new PCR conditions. The initial and improved methods were compared with other existing conventional and real-time PCR methods regarding their sensitivity.

\section{Materials and methods}

\section{Phytoplasma isolates, biological materials and indexing}

The phytoplasma isolates, their host plants and their origins are listed in Table 1. Isolates of $\mathrm{Ca}$. P. mali, 'Ca. P. pyri', and 'Ca. P. prunorum' received in infected periwinkles [Catharanthus roseus (L.) G. Don] were maintained in periwinkles by periodic grafting, and obtained apple plant materials containing the isolates of $\mathrm{Ca}$. P. mali were grafted on apple trees (variety: MM106) by whip or bark grafting in an insect-proof greenhouse. After grafting, suitable conditions for growth were provided: $14 \mathrm{~h}$ of photoperiod, high relative humidity and temperature of $20-25^{\circ} \mathrm{C}$ ). For biological indexing, the appearance of symptoms was timed by monitoring inoculated plants (three periwinkles and four apple trees per isolate).
Table 1 Phytoplasmas and host plants examined in this study

\begin{tabular}{|c|c|c|}
\hline Strain & Sample Form & Provider \\
\hline AT1 & Periwinkle infected & Seemüller (Germany) \\
\hline AT & Periwinkle infected & $\begin{array}{l}\text { Schneider (Germany, } \\
\text { accession no. X68375) }\end{array}$ \\
\hline AP15 & Periwinkle infected & $\begin{array}{l}\text { Schneider (Germany, } \\
\text { accession no. AJ542541) }\end{array}$ \\
\hline AT1/93 & Periwinkle infected & $\begin{array}{l}\text { Schneider (Germany, } \\
\text { accession no. AJ542542) }\end{array}$ \\
\hline AT5/93 & Periwinkle infected & Schneider (Germany) \\
\hline AT12/93 & Periwinkle infected & Schneider (Germany) \\
\hline AT1-proliferation & Apple infected & Pradier (Lempdes, France) \\
\hline AT1-No. 2 & Apple infected & Pradier (Lempdes, France) \\
\hline AP-N17 & Apple infected & Pradier (Lempdes, France) \\
\hline AT1-IDARED & Apple infected & Pradier (Lempdes, France) \\
\hline AT2-SO8D & Apple infected & Pradier (Lempdes, France) \\
\hline LB/AP1 & Extracted DNA & Baric (Bolzano, Italy) \\
\hline LB/AP2 & Extracted DNA & Baric (Bolzano, Italy) \\
\hline AP2174 & Liophylised DNA & $\begin{array}{l}\text { Fialova } \\
\text { (Olomouc, Czech Republic) }\end{array}$ \\
\hline AP2371 & Lyophilised DNA & $\begin{array}{l}\text { Fialova } \\
\text { (Olomouc, Czech Republic) }\end{array}$ \\
\hline AP-Melo1 & Lyophilised DNA & Firrao (Udine, Italy) \\
\hline AP-Melo2 & Lyophilised DNA & Firrao (Udine, Italy) \\
\hline ESFY & Periwinkle infected & Seemüller (Germany) \\
\hline ESFY1 & Extracted DNA & $\begin{array}{l}\text { Bertaccini (Italy, } \\
\text { accession no. AJ542544) }\end{array}$ \\
\hline ESFY2 & Extracted DNA & $\begin{array}{l}\text { Bertaccini (Italy, } \\
\text { accession no. AJ542545) }\end{array}$ \\
\hline PD & Extracted DNA & $\begin{array}{l}\text { Bertaccini (Italy, } \\
\text { accession no. AJ542543) }\end{array}$ \\
\hline PD1 & Periwinkle infected & Seemüller (Germany) \\
\hline EY (16SrV) & Extracted DNA & $\begin{array}{l}\text { Bertaccini (Italy, } \\
\text { accession no. X68376) }\end{array}$ \\
\hline ASLO (16SrXII-A) & Extracted DNA & Bertaccini (Italy) \\
\hline KVM (16Srl-C) & Extracted DNA & Bertaccini (Italy) \\
\hline
\end{tabular}

\section{Phytoplasma DNA extraction}

Fresh apple tree leaf midribs $(0.5 \mathrm{~g})$ were ground in 4-mL extraction buffer ( $2 \%$ cetyltrimethylammonium bromide, $1.4 \mathrm{M} \mathrm{NaCl}, 20 \mathrm{mM}$ ethylenediaminetetraacetic acid, 100 mM Tris-HCl, pH 8.0) with a mortar and pestle. Samples were incubated at $60^{\circ} \mathrm{C}$ for $30 \mathrm{~min}$ and shaken every $5 \mathrm{~min}$. Three millilitres of chloroform/isoamyl alcohol (24:1) were added on ice, and the mixture was vortexed vigorously before centrifugation at $16100 \mathrm{~g}$ for $5 \mathrm{~min}$ at $4^{\circ} \mathrm{C}$. The supernatant was transferred to a clean tube, and after adding an equal volume of ice-cold $\left(-20^{\circ} \mathrm{C}\right)$ isopropanol, the solution was centrifuged at $16100 \mathrm{~g}$ for $8 \mathrm{~min}$ at $4^{\circ} \mathrm{C}$. The pellet was rinsed with $70 \%$ ethanol and dried. An optional ethanol precipitation was also carried out. If required, the total nucleic acid concentration was estimated with a spectrophotometer (LKB Biochrom Ultraspec II, Cambridge, UK). 


\section{Detection of phytoplasma by conventional PCR}

The fU5/rU3 primer pairs and the protocol described by Lorenz et al. (1995) were used to detect phytoplasma by classical PCR. Two adaptations were made: an additional step at $95^{\circ} \mathrm{C}$ for $10 \mathrm{~min}$ (polymerase activation) and amplification by 45 PCR cycles. Primers were obtained from Eurogentec (Liège, Belgium). The $1 \times$ PCR buffer and the HotgoldStar DNA polymerase (Eurogentec) were used. PCR products were electrophoresed through $1.5 \%$ agarose gel and revealed using ethidium bromide under UV illumination.

\section{Cloning and sequencing of PCR products}

The PCR products obtained with the qAP-16S-F/R primers (Baric \& Dalla-Via, 2004; Table 2) were purified from the agarose gel using the QIAEX II purification kit (Qiagen, Hilden, Germany) as recommended by the manufacturer. These fragments were further cloned with the TA Cloning ${ }^{\circledR}$ Kit (Invitrogen, Carlsbad, CA, USA). Plasmids containing the PCR product were extracted according to the ULTRAPrep ${ }^{\circledR}$ PLASMID DNA kit protocol (AHN Biotechnologie, Nordhausen, Germany). The amplified plasmids were either sequenced (by GATC Biotech, Konstanz, Germany) or quantified by optical density at $260 \mathrm{~nm}$. After quantification, 10-fold serial dilutions of the purified plasmid, ranging from 1 to $10^{8}$ copies per PCR, were prepared to evaluate the limit of detection of the method.

\section{Oligonucleotide design}

A new TaqMan MGB probe [with the carboxyfluorescein (FAM) reporter dye] was designed using the 'Primer Express' software version 5.0 (PE Applied Biosystems, Foster City, CA, USA). The design of this new probe was based on our own sequences, corresponding to isolates AP15 (DQ661859) and AT1 (DQ661860) of Ca. P. mali, and based on at least 20 sequences from the NCBI database [six Ca. P. mali isolates: X76426, AJ542542, AJ54254, X68375, AY598319 and AF248958; six Ca. P. prunorum isolates: AY029540, AJ542544, AJ542545, AJ575105, AJ575106 and AJ575107; three isolates of Ca. P. pyri: Y16392, AJ542543 and AJ964959 and some other phyto- plasmas more distinct from AP group including 'Candidatus Phytoplasma ulmi' (X68376), 'Candidatus Phytoplasma asteris' (AF503568), 'Candidatus Phytoplasma solani' (AF248959), 'Candidatus Phytoplasma vitis' (X76560), and strain CPh of 'Ca. P. asteris' (X77482)].

\section{Detection of phytoplasma by real-time PCR using TaqMan MGB probe}

The reactions were carried out in a total volume of $25 \mu \mathrm{L}$ containing 10-100 ng template DNA, $1 \times$ qPCR Master Mix (Eurogentec) containing dUTP, $400 \mathrm{nM}$ of each primer and $200 \mathrm{nM}$ probe. Amplification and detection were performed with the GeneAmp 5700 Sequence Detection System (SDS; PE Applied Biosystems). The thermal cycle consisted of $2 \mathrm{~min}$ at $50^{\circ} \mathrm{C}$ (carry-over inactivation) and $10 \mathrm{~min}$ at $95^{\circ} \mathrm{C}$ (HotGoldStar DNA activation), followed by 45 cycles of $15 \mathrm{~s}$ at $95^{\circ} \mathrm{C}$ and $60 \mathrm{~s}$ at $60^{\circ} \mathrm{C}, 62^{\circ} \mathrm{C}$, or $64^{\circ} \mathrm{C}$. Each reaction included at least one blank without template and one negative control corresponding to healthy plants. All samples and controls were amplified in triplicate. Threshold levels were calculated according to two recommended methods: (a) threshold $=10 \times$ standard deviation $(\mathrm{SD})$ of the fluorescence values during 5 th to 15 th cycle and (b) point of inflexion of the fluorescence curve. The threshold cycle $\left(C_{t}\right)$ value of each PCR reaction was calculated by GeneAmp 5700 SDS software.

\section{Specificity and limit of detection}

The specificity of the real-time PCR using the newly designed probe for $\mathrm{Ca}$. P. mali was assessed using DNA extracts containing other European fruit tree phytoplasma isolates (two Ca. P. pyri and four Ca. P. prunorum) or other more different phytoplasmas (Table 1). The limit of detection of our real-time PCR method was compared with that of four other PCR protocols: one conventional PCR (Lorenz et al., 1995) and three real-time PCRs using TaqMan MGB (Baric and Dalla-Via, 2004) or SYBR Green (Jarausch et al., 2004; Torres et al., 2005) fluorescence chemistry. Forty-five PCR cycles were performed with all protocols. The SYBR Green Mastermix used in the original protocols (Jarausch et al., 2004; Torres et al.,

Table 2 List of primers and probes used for phytoplasma detection

\begin{tabular}{lll}
\hline Name & Sequence $5^{\prime}-3^{\prime}$ & Reference \\
\hline qAP-16S-F & CGAACGGGTGAGTAACACGTAA & Baric \& Dalla-Via (2004) \\
qAP-16S-R & CCAGTCTTAGCAGTCGTTTCCA & Baric \& Dalla-Via (2004) \\
qAP-16S & FAM-TAACCTGCCTCTTAGACG-MGB & Baric \& Dalla-Via (2004) \\
AP-MGB & FAM-CTGCCTCTTAGACGAGG-MGB & Designed in this study \\
\hline
\end{tabular}

MGB, minor groove binding. 
2005) was employed. Three samples, from three different apple trees, were extracted independently from leaves (A and C) or vascular tissue (B). Ten-fold serial dilutions $\left(10^{-1}\right.$ to $\left.10^{-8}\right)$ were prepared from each sample. Each dilution was amplified twice independently in triplicate.

\section{Results}

Real-time PCR and new probe design

In our experiments, target DNA from all Ca. P. mali isolates (Table 1) was successfully detected with the qAP16S probe (Table 2) and a hybridisation temperature of $60^{\circ} \mathrm{C}$ (Baric and Dalla-Via, 2004). No signal was obtained from healthy plants (apple or periwinkle), but significant fluorescence signals were also detected for $\mathrm{Ca}$. P. prunorum. and $\mathrm{Ca}$. P. pyri isolates. The amplification curves of the $\mathrm{Ca}$. P. prunorum samples were sigmoid like those of the $\mathrm{Ca}$. P. mali samples and crossed the threshold line set by either the $10 \times \mathrm{SD}$ or the inflexion point method. A positive signal was still observed for $\mathrm{Ca}$. P. prunorum samples with the hybridisation temperature of $62^{\circ} \mathrm{C}$ or $64^{\circ} \mathrm{C}$, but the amplification curves were not completely sigmoid and the final fluorescence was much lower (Fig. 1).

Therefore, a sequencing effort and a sequence alignment (Fig. 2) were carried out to select a new TaqMan MGB probe (AP-MGB). Sequence alignments showed that the fragments amplified from our $\mathrm{Ca}$. P. mali strains were $100 \%$ identical to the previously published $\mathrm{Ca}$. P. mali sequences. They also revealed that the $\mathrm{Ca}$. P. prunorum isolates used in this study had only one mismatch with the qAP-16S probe (nucleotide at position 36 in Fig. 2). Our new probe was designed to locate the mismatch in the middle part of the probe (Fig. 2). This probe displayed no mismatch with any of the six Ca. P. mali sequences. It did display mismatches with the Ca. P. prunorum sequences (one or two mismatches), Ca. P. pyri sequences (three mismatches), other more distant phytoplasmas (at least two mismatches) and also with unspecific amplicons obtained from healthy plants (seven mismatches, Fig. 2). With the AP-MGB probe and a hybridisation temperature of $64^{\circ} \mathrm{C}$, specific detection of Ca. P. mali was achieved (Fig. 1) without crossamplification of DNA from any other phytoplasma
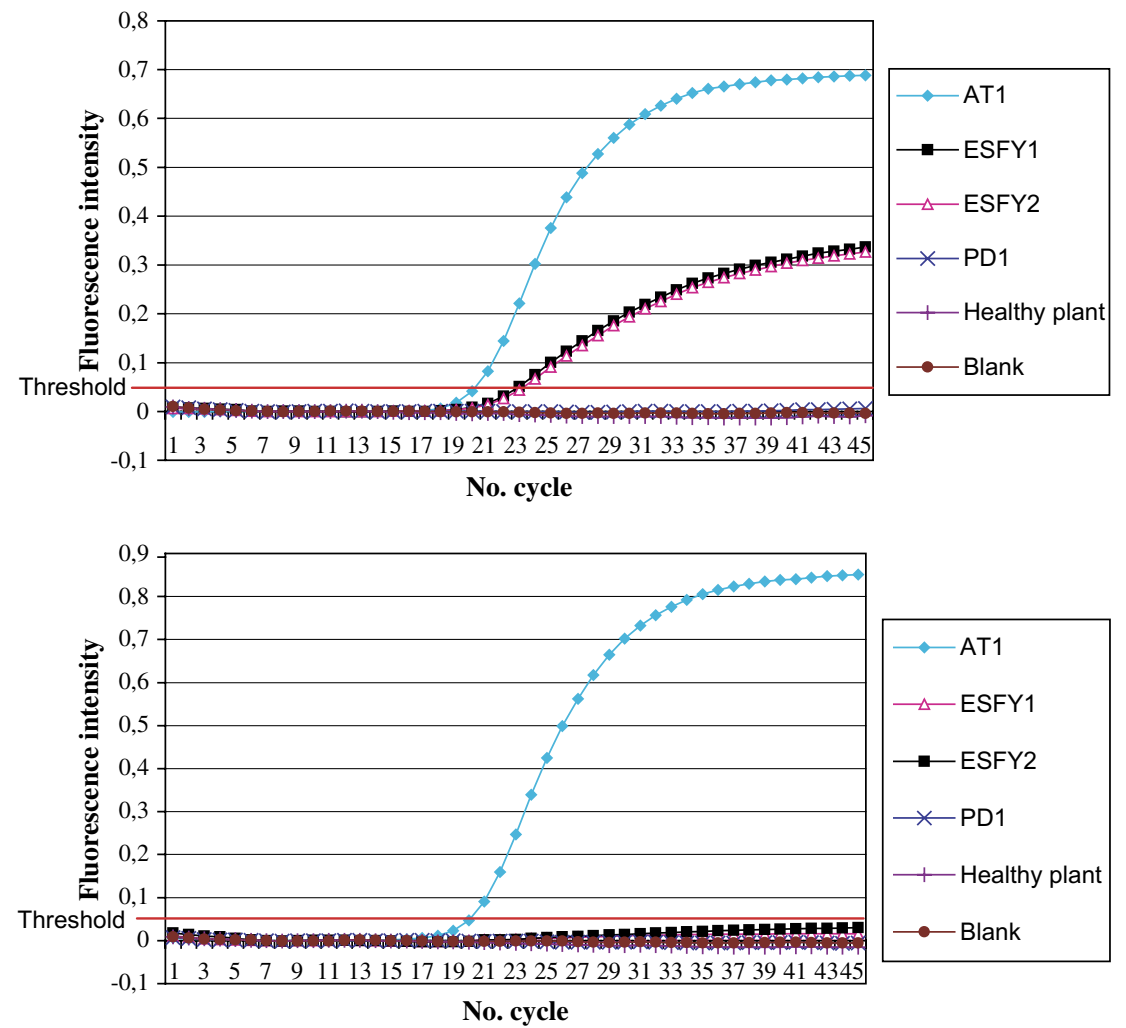

Figure 1 Fluorescent intensity (delta Rn) of amplification of different phytoplasma isolates, 'Ca. P. mali' (AT1), 'Ca P. prunorum' (ESFY1and ESFY2) and 'Ca P. pyri' (PD1) obtained by real-time PCR using qAP-16S-F/R primers and qAP-16S (upper diagram) or AP-MGB (lower diagram) probes at 64 ${ }^{\circ} \mathrm{C}$ as hybridisation temperature. 


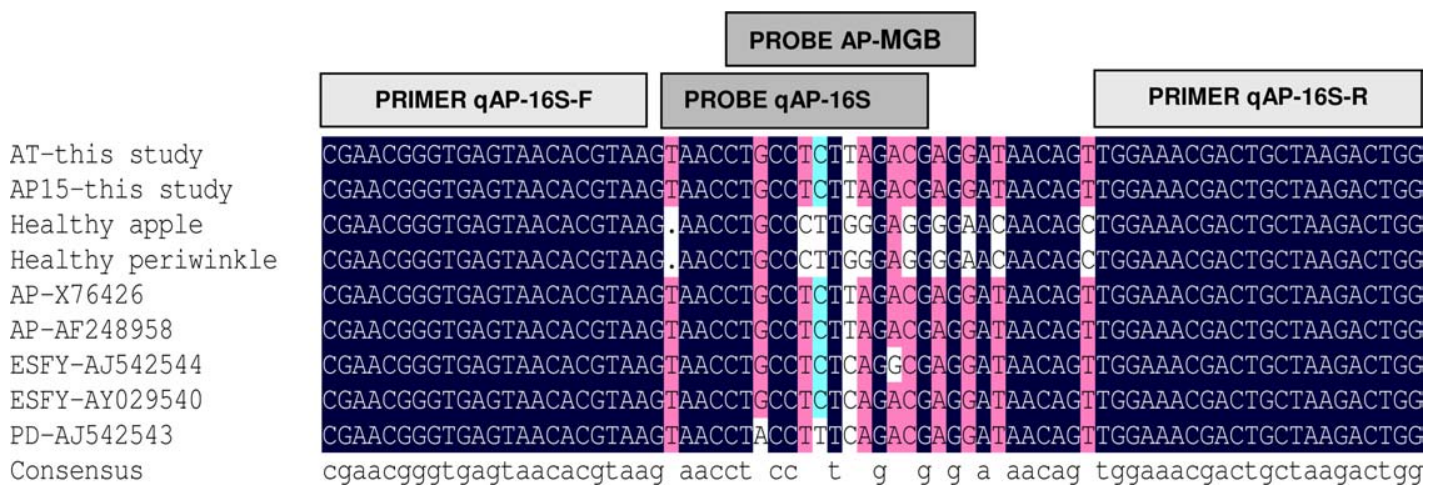

Figure 2 Alignment comparison of a sequenced region of $16 \mathrm{~S}$ rRNA gene in two strains of 'Ca. P. mali' (AT and AP15) and two healthy samples (apple and periwinkle) with reference strains of 'Ca. P. mali', 'Ca. P. prunorum' (ESFY) and 'Ca. P. pyri' (PD). In sequence alignments, the dots mean absence of nucleotide.

species detailed in Table 1, whatever the methodology used to select the threshold (Fig. 1).

\section{Limits of detection of conventional and real-time PCR protocols}

Our new real-time PCR assay successfully detected a single copy of plasmid in water (Table 3). When the plasmid was diluted in DNA extract from healthy plants, 100 plasmid copies were still detected reproducibly.

We then compared the limits of detection of the five PCR protocols. The classical PCR protocol successfully detected the phytoplasma down to dilution $10^{-5}$ of samples $\mathrm{A}$ and $\mathrm{B}$ and down to dilution $10^{-4}$ of sample $\mathrm{C}$ (data not shown). Both real-time PCR protocols using SYBR Green (Jarausch et al., 2004; Torres et al., 2005) displayed a reproducible limit of detection of $10^{-5}$ whatever the sample. Both real-time PCR protocols using TaqMan MGB probes successfully detected the target in each sample and each PCR run down to dilution $10^{-6}$ (data not shown).

Table $3 C_{t}$ values of serial dilution of standard (plasmid) prepared in water or DNA extract of healthy plants (pure or 100-fold diluted in water)

\begin{tabular}{lll}
\hline $\begin{array}{l}\text { Standard Copy } \\
\text { Number in PCR Reaction }\end{array}$ & $\begin{array}{l}\text { Standard Prepared } \\
\text { in Water }\end{array}$ & $\begin{array}{l}\text { Standard Prepared } \\
\text { in DNA Extract } \\
\text { of Healthy Apples }\end{array}$ \\
\hline One copy $_{10 \text { copies }}$ & 40.37 & ND \\
$10^{2}$ copies & 36.18 & ND \\
$10^{3}$ copies & 33.31 & 44.72 \\
$10^{4}$ copies & 30.53 & 34.42 \\
$10^{5}$ copies & 27.77 & 28.66 \\
\hline
\end{tabular}

ND, not-detected.

${ }^{a}$ There was no significant difference between $C_{t}$ values of different treatment of standard from $10^{5}$ to $10^{8}$ copies (LSD test available as SAS software, $P<0.05)$.
Detection of phytoplasma after grafting by biological indexing and PCR

The appearance of symptoms was periodically surveyed (Table 4). Three months after grafting of infected materials on periwinkles, the symptoms of phytoplasma disease (yellowing and reduced leaf size) were conspicuous on $71 \%$ of the plants. Only after 4 months, did all the plants display proliferation symptoms. On grafted MM106 rootstocks, $10 \%$ of the plants showed symptoms after 4 months. After 7 months, $25 \%$ of the plants still showed no symptoms.

Phytoplasma infection was also evaluated by conventional PCR using the universal primer pair fU5/rU3 (Table 4). It was detected in all periwinkle and apple plants after 4 and 7 months, respectively. Symptom indexing and conventional PCR detected $100 \%$ of the infected periwinkles at the same moment (at 4 months), but a higher percentage of infected plants was detected by conventional PCR than by symptom indexing during the second and third months for periwinkle and from the second to seventh month for apple. Conventional PCR thus has an important advantage: the ability to detect $\mathrm{Ca}$. P. mali in all infected apple trees within 7 months.

The third method used to detect phytoplasma was our new real-time PCR protocol (Table 4). It proved even more advantageous than the conventional PCR protocol, detecting $\mathrm{Ca}$. P. mali infection in all grafted plants, both periwinkle and apple, only 3 months after grafting, that is earlier than either conventional PCR or biological indexing.

\section{Discussion}

In this study, we have designed a new MGB probe and new PCR conditions to improve the specificity of $\mathrm{Ca}$. P. 
Table 4 Results of indexing and detection of phytoplasma by different PCR methods in different periods after grafting the infected samples on healthy plants in greenhouse

\begin{tabular}{|c|c|c|c|c|c|c|}
\hline \multirow[b]{2}{*}{ Period } & \multicolumn{2}{|c|}{ Symptom Indexing } & \multicolumn{2}{|c|}{ Conventional $\mathrm{PCR}^{\mathrm{a}}$} & \multicolumn{2}{|l|}{ Real-time $P C R^{b}$} \\
\hline & Periwinkle (\%) & Apple (\%) & Periwinkle (\%) & Apple (\%) & Periwinkle (\%) & Apple (\%) \\
\hline First month (15 days) & $0^{d}$ & 0 & NT & 0 & NT & 5 \\
\hline Second month (40 days) & 26 & 0 & 50 & 35 & 71 & 70 \\
\hline Third month (70 days) ${ }^{c}$ & 71 & 0 & 96 & 80 & 100 & 100 \\
\hline Fourth month ${ }^{c}$ & 100 & 10 & 100 & 90 & 100 & 100 \\
\hline Seventh month ${ }^{c}$ & 100 & 75 & 100 & 100 & 100 & 100 \\
\hline
\end{tabular}

NT, not-tested.

${ }^{a}$ Amplification using universal primers fU5/rU3 (Lorenz et al., 1995)

${ }^{b}$ Our real-time PCR protocol by AP-minor groove binding probe.

cDetection of phytoplasma in one leaf midrib.

${ }^{d}$ Percentage of positive samples versus total number of tested plants (24 periwinkles and 20 apples).

mali detection. Our new real-time PCR protocol detects in water a single copy of DNA target per reaction and is ten times more sensitive than the conventional PCR protocol and two SYBR Green real-time PCR protocols.

We first tested the qAP-16S probe designed by Baric $\delta$ Dalla-Via (2004). In our hands, this probe was not specific for $\mathrm{Ca}$. P. mali detection because $\mathrm{Ca}$. P. prunorum isolates were also detected. This result may be because of two factors: (a) the Ca. P. prunorum isolates used in our study only have a single mismatch with the sequence of the $\mathrm{qAP}-16 \mathrm{~S}$ probe, whereas those of Baric \& Dalla-Via (2004) had two mismatches and (b) the threshold line was set by inflexion point in the previous publication (Baric \& Dalla-Via, 2004).

The position of a mismatch is crucial to the specificity of an MGB probe. MGB probes have been successfully employed to detect single-nucleotide mutations in the central region (Marbot et al., 2002; Salmon et al., 2002b) or the 3' terminal region (Kutyavin et al., 2000; Salmon et al., 2002a; Massart et al., 2005) of the probe. Yao et al. (2006) observed that two mismatches in the centre of the probe-annealing region generated a signal in their MGB probe assay. Here, a single mismatch within the annealing region of the qAP-16S probe also generated a fluorescence signal. In both studies, similar fluorescence curves were obtained, with low fluorescence increases and low final delta Rn values. This low level of fluorescence for $\mathrm{Ca}$. P. prunorum isolates was below the threshold line set by the inflexion point method but not below the line set by the $10 \times$ SD method. Besides, an MGB probe may require careful optimisation to allow specific detection (Yao et al., 2006). Under our optimised PCR conditions, the newly designed TaqMan MGB probe successfully detected all three described subtypes (Jarausch et al., 2000) of Ca. P. mali (AP, AT1 and AT2) of different geographical origins, while no signal was observed with strains belonging to closely related phyto- plasmas. This new TaqMan MGB probe thus showed higher specificity. Under these PCR conditions, the singlenucleotide polymorphism was detected more readily when located in the central region of the probe (position 9 out of 17) than in the $3^{\prime}$ region (position 13 out of 18 ).

This new Ca. P. mali-specific probe can be helpful in ascertaining the presence of $\mathrm{Ca}$. P. mali specifically. The finding that a single host plant can be doubly or multiply infected by different phytoplasmas (Bianco et al., 1993; Lee et al., 1994, 1995) suggests that the aetiologies of diseases associated with perennial fruit crops may be particularly complex. Fruit trees might harbour other phytoplasmas, and as several apple-growing areas worldwide have not yet been surveyed, we cannot just assume that $\mathrm{Ca}$. P. mali is the only phytoplasma affecting apple.

The new protocol and that of Baric and Dalla-Via (2004) display similar sensitivity. Both are 10-100 times more sensitive than classical PCR protocol and 10 times more sensitive than two other real-time PCR protocols. This difference between real-time PCR protocols in sensitivity may be because of fluorescence chemistry, primer efficiency or the real-time PCR cycler. Clearly, this difference should be confirmed and better investigated through, for example, an interlaboratory comparison of these methods.

In our grafting experiments, the new real-time PCR protocol detected $100 \%$ of the infected material earlier than classical PCR or symptom observation. This confirms the higher sensitivity of real-time PCR and should be useful in the framework of a certification programme, where early detection of the infected status of a suspicious sample after grafting is of the essence. Importantly, in the case of a quarantine organism, high sensitivity should also make it possible to improve disease control through earlier detection Ca. P. mali in an infected tree. The earlier eradication measures can be taken, the lower the risk of contaminating other trees in the orchard. As mentioned 
previously (Mumford et al., 2006), real-time PCR is a reliable, quick and simple molecular method, well suited for high-throughput analysis of numerous samples.

In summary, we have designed a new real-time PCR protocol with improved specificity and high sensitivity to detect $\mathrm{Ca}$. P. mali. This technique has great potential as a routine diagnostic tool in a procedure of plant nursery certification.

\section{Acknowledgements}

We are grateful to A. Bertaccini for critical reading of the manuscript. We thank A. Bertaccini, E. Seemüller, B. Schneider, B. Pradier, S. Baric, G. Firrao and R. Fialova for providing phytoplasma strains. J. Kummert, C. Bragard, R. Kettmann, O. Dutrecq and S. Steyer offered useful advice and suggestions, which we appreciate sincerely.

\section{References}

Aldaghi M., Kummert J., Roussel S., Jijakli M.H. (2005) A molecular investigation to identify phytoplasmas associated with fruit trees. Communications in Agricultural and Applied Biological Sciences, 70, 253-255.

Andersen M.T., Beever R.E., Gilman A.C., Liefting L.W., Balmori E., Beck D.L., Sutherland P.W., Bryan G.T., Gardner R.C., Forster R.L.S. (1998) Detection of phormium yellow leaf phytoplasma in New Zealand flax (Phormium tenax) using nested PCRs. Plant Pathololgy, 47, 188-196.

Baric S., Dalla-Via J. (2004) A new approach to apple proliferation detection: a highly sensitive real-time PCR assay. Journal of Microbiological Methods, 57, 135-145.

Bianco P.A., Davis R.E., Prince J.P., Lee I.-M., Belli G.U. (1993) Double and single infections by aster yellows and elm yellows MLOs in grapevines with symptoms characteristic of flavescence dorée. Journal of Plant Pathology (Rivista di Pathologia Vegetale), 3, 69-82.

EPPO/CABI. (1996) Apple proliferation phytoplasma. In Quarantine Pests for Europe. 2nd edn, pp. 959-962. Eds I.M. Smith, D.G. McNamara, P.R. Scott and K.M. Harris. Wallingford, UK: CAB International.

Frisinghelli C., Delaiti L., Grando M.S., Forti D., Vindimian M.E. (2000) Cacopsylla costalis (Flor 1861), as a vector of apple proliferation in Trentino. Journal of Phytopathology, $148,425-431$.

Jarausch W., Saillard C., Helliot B., Garnier M., Dosba F. (2000) Genetic variability of apple proliferation phytoplasmas as determined by PCR-RFLP and sequencing of a non-ribosomal fragment. Molecular and Cellular Probes, $14,17-24$

Jarausch W., Peccerella T., Schwind N., Jarausch B., Krczal G. (2004) Establishment of a quantitative real-time PCR assay for the quantification of apple proliferation phyto- plasmas in plants and insects. Acta Horticulturae, 657, 415-420.

Kutyavin I.V., Afonina I.A., Mills A., Gorn V.V., Lukhtanov E.A., Belousov E.S., Singer M.J., Walburger D.K., Lokhov S.G., Gall A.A., Dempcy R., Reed M.W., Meyer R.B., Hedgpeth J. (2000) 3'-minor groove binder-DNA probes increase sequence specificity at PCR extension temperatures. Nucleic Acids Research, 28, 655-661.

Lee I.-M., Gundersen D.E., Hammond R.W., Davis R.E. (1994) Use of mycoplasmalike organism (MLO) groupspecific oligonucleotide primers for nested-PCR assays to detect mixed-MLO infections in a single host plant. Phytopathology, 84, 559-566.

Lee I.-M., Zhu S., Gundersen D.E., Zhang C., Hadidi A. (1995) Detection and identification of a new phytoplasma associated with cherry lethal yellows in China (Abstract). Phytopathology, 85, 1179.

Lee I.-M., Gundersen-Rindal D.E., Davis R.E., Bartoszyk I.M. (1998) Revised classification scheme of phytoplasmas based on RFLP analyses of 16S rRNA and ribosomal protein gene sequences. International Journal of Systematic Bacteriology, 48, 1153-1169.

Lorenz K.H., Schneider B., Ahrens U., Seeműller E. (1995) Detection of the apple proliferation and pear decline phytoplasmas by PCR amplification of ribosomal and nonribosomal DNA. Phytopathology, 85, 771-776.

Marbot S., Kummert J., Salmon M., Vendrame M., Huwaert A., Dutrecq O., Lepoivre P. (2002) Development of RT-PCR tests for the routine detection of latent and ILAR viruses in fruit trees. Plant Protection Science, 38, 21-23.

Massart S., De Clercq D., Salmon M., Dickburt C., Jijakli M.H. (2005) Development of real-time PCR using Minor Groove Binding probe to monitor the biological control agent Candida oleophila (strain O). Journal of Microbiological Methods, 60, 73-82.

McCoy R.E., Caudwell A., Chang C.J., Chen T.A., Chiykowski L.N., Cousin M.T., Dale de Leeuw G.T.N., Golino D.A., Hackett K.J., Kirkpatrick B.C., Marwitz R., Petzold H., Sinha R.H., Sugiura M., Whitcomb R.F., Yang I.L., Zhu B.M., Seemüller E. (1989) Plant diseases associated with mycoplasmalike organisms. In The Mycoplasmas. Volume 5, pp. 545-640. Eds R.F. Whitcomb and J.O. Tully. New York, NY, USA: Academic Press.

Mumford R., Boonham N., Tomlinson J., Barker I. (2006) Advances in molecular phytodiagnostics - new solutions for old problems. European Journal of Plant Pathology, 116, $1-19$.

Salmon M.A., Vendrame M., Kummert J., Lepoivre P. (2002a) Detection of apple chlorotic leaf spot virus using a 5' nuclease assay with a fluorescent 3' minor groove binder-DNA probe. Journal of Virological Methods, 104, 99-106.

Salmon M.A., Vendrame M., Kummert J., Lepoivre P. $(2002 b)$ Rapid and homogeneous detection of apple stem pitting virus by RT-PCR and a fluorogenic 3' minor groove 
binder-DNA probe. European Journal of Plant Pathology, 108, 755-762.

Seemüller E., Schneider B. (2004) 'Candidatus Phytoplasma mali', 'Candidatus Phytoplasma pyri' and 'Candidatus Phytoplasma prunorum', the causal agents of apple proliferation, pear decline and European stone fruit yellows, respectively. International Journal of Systematic and Evolutionary Microbiology, 54, 1217-1226.

Seemüller E., Kison H., Lorenz K.H., Schneider B., Marcone C., Smart C.D., Kirkpatrick B.C. (1998) Detection and identification of fruit tree phytoplasmas by PCR amplification of ribosomal and non ribosomal DNA. In New Technologies to Improve Phytodiagnosis: Advances in the Detection of Plant Pathogens by Polymerase Chain Reaction, pp. 56-66.

Eds C. Manceau and J. Spak. Luxemburg: Office of the Official Publication of the European Community.

Torres E., Bertolini E., Cambra M., Monton C., Martin M.P. (2005) Real-time PCR for simultaneous and quantitative detection of quarantine phytoplasmas from apple proliferation (16SrX) group. Molecular and Cellular Probes, 19, 334-340.

Van Hoeyveld E., Houtmeyers F., Massonet C., Moens L., Van Ranst M., Blanckaert N., Bossuyt X. (2004) Detection of single nucleotide polymorphisms in the mannosebinding lectin gene using minor groove binder-DNA probes. Journal of Immunological Methods, 287, 227-230.

Yao Y., Nellaker C., Karlsson H. (2006) Evaluation of minor groove binding probe and Taqman probe PCR assays: influence of mismatches and template complexity on quantification. Molecular and Cellular Probes, 20, 311-316.

Yoshitomi K.J., Jinneman K.C., Weagant S.D. (2003) Optimization of a 30-minor groove binder-DNA probe targeting the uidA gene for rapid identification of Escherichia coli O157:H7 using real-time PCR. Molecular and Cellular Probes, 17, 275-280. 